\title{
Identity and Entrepreneurship
}

\author{
OLIVER FALCK \\ STEPHAN HEBLICH \\ ELKE LUEDEMANN
}

CESIFO WORKING PAPER NO. 2661

CATEgORY 4: LABOUR MarketS

MAY 2009
An electronic version of the paper may be downloaded
- from the SSRN website: Www.SSRN.com
- from the RePEc website: $\quad$ www.RePEc.org
- from the CESifo website: www.CESifo-group.org/wp




\title{
Identity and Entrepreneurship
}

\begin{abstract}
We incorporate the concept of social identity into a stylized model of occupational choice and analyze whether an individual's identity affects his or her decision to become an entrepreneur. We argue that an entrepreneurial identity results from an individual's socialization. This could be parental influence but, as argued in this paper, also peer influence. To test this empirically, we apply instrumental variable approaches to PISA data. Our findings suggest that having an entrepreneurial peer group has a positive effect on an individual's entrepreneurial intentions. Regarding entrepreneurial parents, we find a positive effect that cannot only be explained by ownership succession of the family business.
\end{abstract}

JEL Code: J24, L26, Z13.

Keywords: occupational choice, entrepreneurship, identity, peer effects.

Oliver Falck
Ifo Institute for Economic Research at the
University of Munich
Poschingerstrasse 5
81679 Munich
Germany
falck@ifo.de

Stephan Heblich
Max Planck Institute of Economics
Kahlaischestrasse 10
07745 Jena
Germany
heblich@econ.mpg.de

Stephan Heblich

Kahlaischestrasse 10

07745 Jena

mpg.de

\author{
Elke Luedemann \\ Ifo Institute for Economic Research at the \\ University of Munich \\ Poschingerstrasse 5 \\ 81679 Munich \\ Germany \\ luedemann@ifo.de
}

This version: 14 May 2009

We are grateful to David Audretsch, Oliver Kirchkamp, Mirjam van Praag, Simon Parker, and Ludger Wößmann for helpful comments on an earlier version of this paper. 


\section{Introduction}

There is a great deal of research into what motivates an individual to become an entrepreneur, taking into consideration extant conditions and institutions that either support or impede entrepreneurial intentions. ${ }^{1}$ One major finding in this research is that entrepreneurs are willing to accept a lower expected income than what standard economic models of occupational choice would suggest (Evans \& Leighton 1989; Hamilton 2000), suggesting that there is some type of nonpecuniary value to being an entrepreneur that, at first glance, makes little sense from a standard economic perspective. However, drawing on well-established insights from the fields of sociology and psychology, Akerlof and Kranton (2000) introduced the concept of identity, meaning a person's self-image, into an economic utility function. They argue that individuals earn additional utility from an identity that matches their ideals. Eventually, this nonmonetary incentive can explain occupational choices that vary from what would be optimum for a rational actor in a standard economic model.

Following Akerlof and Kranton's concept of identity, this paper chooses entrepreneurship as setting and argues that identity plays an important role in explaining an individual's motivation to become an entrepreneur, with consequent effects on his or her economic future. To analyze where an entrepreneurial identity actually comes from, we start with the existing literature on the intergenerational transmission of entrepreneurial intentions (cf. Aldrich et al. 1998; Hout and Rosen 2000; Johnson 2002). Contributions in this field assume that children who grow up in an entrepreneurial household are more likely to become entrepreneurs themselves. ${ }^{2}$ Moreover, a large body of literature suggests that it is not just parents but also peers, i.e. friends of the same age that are usually classmates, that influences an individual's identity. To account for the additional effect of peers in developing entrepreneurial intentions, this paper posits that an entrepreneurial identity is

\footnotetext{
${ }^{1}$ For instance, Kihlstrom and Laffont (1979) analyze occupational choice with regard to an individual's risk aversion, Lucas (1978) considers innate abilities, and Lazear (2005) stresses the importance of an individual's mix of skills. Yet others analyze the impact of external constraints (e.g., Holtz-Eakin et al. 1994; Michelacci \& Silva 2007), social contacts (e.g., Bauernschuster et al. 2008; Stuart \& Sorenson 2005). For an extensive overview, see Parker (2004).

${ }^{2}$ Note that this choice is not only determined by the obligation to take over the family business but also by transmitted virtues like independence or self-reliance.
} 
shaped by entrepreneurial parents and entrepreneurial peers. To identify the effects of parents and peers empirically, we employ PISA data and find evidence that, indeed, having entrepreneurial parents and/or entrepreneurial peers increases the likelihood that an individual will have entrepreneurial intentions. These results even hold when applying instrumental variables approaches to identify endogenous peer effects.

The rest of the paper is organized as follows. In Section 2, we first sketch our hypothesized connection between identity and entrepreneurship. Focusing on how an entrepreneurial identity originates lays the groundwork for our idea that an individual's parents and his or her social environment will play an important role in the shaping of that identity. In Section 3, we describe our data and then, in Section 4, we set out the empirical strategy we use to test our theory of identity and entrepreneurship. Section 5 presents the results of our empirical analysis and then, Section 6 concludes.

\section{Identity and Entrepreneurship}

\section{Identity as a Contribution to Standard Economic Theory}

Although a familiar and well-developed concept in the fields of psychology and sociology, identity, defined as a person's sense of self, has not attracted too much interest among economists, ${ }^{3}$ until Akerlof and Kranton (2000) introduced the concept to this field. ${ }^{4}$ Akerlof and Kranton argue that standard economics that is based on the concept of methodological individualism mainly concentrates on maximizing given objective functions of individual or collective agents, such as consumers or firms. In this setup, all individuals are aware of their own motivations and then maximize their utility or profits independently of each other. However, an individual's utility actually might not be determined exclusively by individual considerations but also influenced by social desirability considerations, i.e., by an individual's view of who he or she is and what the individual and others should or should not do to live up to this ideal concept of the self. In consequence, norms and prescriptions arise endogenously from social interaction and

\footnotetext{
3 "Because of its explanatory power, numerous scholars in psychology, sociology, political science, anthropology, and history have adopted identity as a central concept. This paper shows how identity can be brought into economic analysis, allowing a new view of many economic problems" (Akerlof \& Kranton 2000: 716).

${ }^{4}$ An exemption is the work by Sen (1977).
} 
then affect individual behavior. Therefore, overall outcomes are likely to differ from what is predicted by models based on methodological individualism because "norms of appropriate and inappropriate behavior differ across space and time" (Akerlof \& Kranton 2005: 12).

People's interactions usually produce externalities that affect movement toward socially beneficial equilibria. Hence, how an individual's utility depends on the utility or the actions of others must be taken into consideration when investigating individuals' true motivation. To account for that, Akerlof and Kranton (2000) introduce a modified utility function that considers identity as a motivation for behavior. In this utility function, identity arises from assignment to social categories. When maximizing their utility, individuals strive to live up to their ideal, which might be someone they know or even an imaginary person possessed of desirable characteristics. An obvious example of an ideal is the founder or prophet of the religion one believes in, but an ideal could also be an outstanding scientist like Einstein, a successful businessperson, or simply a "good" parent. For the individual, the ideal combines one or a set of characteristics a person would like to emulate and failing to do so can result in feelings of shame and other distress. In economic terms, the individual suffers a loss in utility that depends on the distance of his or her behavior from that of the self-chosen ideal. And as the interpretation of an ideal and the corresponding identity-based utility is also affected by an individual's environment and other's actions, identity formation is a dynamic process in which choice of identity also and of necessity affects economic decisions and thus should be taken into account.

Akerlof and Kranton's (2000) concept of identity is a further development of Akerlof's (1997) initial contribution on social distance and social decisions. Extending previous work by Becker (1991) and Becker and Murphy (1993), Akerlof (1997) points out that social decisions differ categorically from conventional economic decisions because "social decisions have social consequences whereas economic decisions do not. While my network of friends and relatives are not affected in the least by my choice between apples and oranges, they will be affected by my educational aspirations, my attitudes and 
practices toward racial discrimination, my childbearing activities, my marriage or divorce, and my involvement in drugs" (Akerlof 1997: 1006).

To capture these externalities, Akerlof (1997) presents two models: people either try to increase social distance (status seeking) or align themselves more closely (conformist behavior) with certain social categories. Akerlof then analyzes how these motivations affect movement toward socially beneficial equilibria. In this framework, social categories are exogenously given. However, social categories really do not just burst into being full-blown, but arise endogenously through feedback loops, such as when one person's actions have meaning for and evoke responses in others (Manski 1995). This more sophisticated view of social categories is a more recent development (Akerlof and Kranton 2000) and is the basis for our analysis.

\section{Identity and Entrepreneurship}

One area where the influence of identity on behavior and economic outcomes is likely to provide additional explanatory power is the field of entrepreneurship. Research in this field owes a large debt to the seminal contributions of Schumpeter (1912) and Knight (1921), which, when taken together, comprise an entrepreneur's most essential attributes: innovativeness, opportunity recognition, and acceptance of a certain degree of risk (Baumol 1968). In a nutshell, Schumpeter sees the independent entrepreneur as the ultimate source of economic development by being the one who recognizes the potential of an invention and introduces it to the market. By innovating, the entrepreneur initiates a process of creative destruction in which the new constantly replaces the old. With time, this ongoing crowding-out process guarantees that resources are shifted to the most productive sectors. As to what drives the entrepreneurial spirit, Schumpeter rather romantically describes it as "the will to conquer," "the dream and the will to found a private kingdom," and "the joy of creating, of getting things done" (1912: 93).

From a standard economic perspective, the Schumpeterian motivation for entrepreneurial action - conquering, founding, and creating - that helps the entrepreneur to overcome Knightian (1921) uncertainty inherent in the endeavor seems rather lyrical than theory driven. Arrow (1962) provides some weightier economic reasoning when he argues that, 
under uncertainty, information becomes a commodity with economic value, implying that those individuals who find a way to overcome uncertainty can appropriate a pioneer rent that is in itself an incentive to engage in entrepreneurial action (Kanbur \& Ravi 1990; Hamilton 2000). However true this may be, it still does not answer the crucial question of why some people manage to overcome uncertainty better and more successfully than others, that is: Why are some people more entrepreneurial than others? We argue that the concept of identity can help answer this question.

The answer cannot be found in a purely economic environment, however, but will need to be looked for in an interdisciplinary arena. On the supra-individual level, the quest leads us to sociological network theory, which stresses the importance of social embeddedness (Coleman 1988; Granovetter 1985; Hayek 1937). According to this theory, social networks provide access to information that makes the future more predictable and thus decreases uncertainty (cf. Bauernschuster et al. 2008; Sanders \& Nee 1996; Stuart \& Sorenson 2005). On the individual level, we need to look to the emerging field of behavioral economics where psychology comes into play (Kahneman \& Tversky, 1979). ${ }^{5}$ According to this field, many factors, including optimism, self-assessment, autonomy, and overall job satisfaction, influence the ideal that an individual will try to live up to (cf. Camerer \& Lovallo 1999; Wu \& Knott 2006). Thus, choosing an entrepreneurial identity means that an individual mentally frames certain situations as being entrepreneurial and then adjusts his or her behavior accordingly. The individual tries to live up to, or emulate, a real or imagined character, for example, Bill Gates or the Schumpeterian Entrepreneur, who is a personification of the entrepreneur he or she would like to be. Consequently, the would-be entrepreneur suffers a loss in utility if his or her behavior strays from this ideal, thus determining the individual's situation-dependent utility (Kahneman \& Tversky 1979).

\footnotetext{
${ }^{5}$ Note in this regard that there is a growing literature on entrepreneurial behavior in the field of strategic management research that focuses on entrepreneurial behavior from a psychological perspective. See, e.g., Baron (1998) and Mitchell and Shepherd (2008).
} 


\section{A Stylized Occupational Choice Model with Identity}

To formally integrate identity into the entrepreneurship decision, let us consider the standard occupational choice model initially introduced by Kilstrom and Laffont (1979). In the simplest form of this model, potential entrepreneurs $E$ choose between starting a business, thereby earning an expected income $y_{E}$, or being dependently employed $D$ and earning a given income $y_{D}$. Given individual risk aversion, the potential entrepreneur will start and run a business as long as the expected utility from future profits and entrepreneurial work effort $e_{E}$ exceeds the utility from future earnings from dependent employment and the corresponding work effort $e_{D}$.

According to Akerlof and Kranton (2000), an individual's utility is additionally influenced by whether or not the occupation matches the individual's self-image. To integrate this possibility, we consider additionally an identity element $I_{c}$ where $c=\{E ; D\}$ captures the occupation category (Akerlof and Kranton 2005). This leads to the following parsimonious utility function:

$$
E u\left(\tilde{y}_{i E}\right)-e_{E} \geq u\left(y_{D}\right)-e_{D}-I_{E} .
$$

According to that, an individual who regards herself as an entrepreneur $E$ and has chosen to be an entrepreneur will have the identity utility $I_{E}$ and choose an effort level $e_{E}$ in the entrepreneurial occupation. Therefore, an individual would choose to be an entrepreneur even though it means both a lower expected income and more effort if the ideal utility from being an entrepreneur is high enough, i.e., exceeds the utility from working as a dependent employee at a given wage $y_{D}$ and effort $e_{D}$. This utility derived from living up to one's entrepreneurial ideal goes much farther toward explaining the decision to become an entrepreneur than that provided by Schumpeter's more romantic "will to conquer" (1912: 93). 


\section{The Transmission of an Entrepreneurial Identity}

According to Schumpeter, the entrepreneur is the driver of innovation and change in an economic system. ${ }^{6}$ Accordingly, there is a keen interest into the question of how best to develop and educate entrepreneurs. It is nearly standard practice now for business schools to offer entrepreneurship courses, in which students learn how to write business plans, meet successful entrepreneurs who tell their powerful and attractive success stories, and also often receive individual-level technical advice and assistance in starting up a business. ${ }^{7}$ However, having an entrepreneurial identity, as we define it in this paper, is not something that can be taught: ${ }^{8}$ students can be taught specific practices and techniques, but they cannot be schooled in the famous "will to conquer." This essential attribute of entrepreneurship is more likely to develop out of a person's background and experience. $^{9}$

Economic research on what factors drive the formation of cognitive and non-cognitive skills usually adopts a life-cycle perspective, and stresses the important influence of experiences during early childhood years (cf. Heckman 2006; Cunha and Heckman $2007)^{10}$. The reasoning for why early childhood experiences have proven so important is that later investments in skills build on foundations that are laid down earlier. The fact that young children spend most of their time with their parents can help explain the strong impact of parental background on educational attainment and student performance we observe across countries all over the world (e.g. OECD 2007a, b). Considering that identity, along with various skills, results from an individual's socialization at home and in school (cf. Akerlof \& Kranton 2005: 12), it seems plausible to assume that an

\footnotetext{
${ }^{6}$ See Baumol (1968) and, for a formal integration of Schumpeter's ideas into economic (growth) theory, Aghion and Howitt (1992).

${ }^{7}$ See Kuratko (2005) for further details about the emergence of entrepreneurship education. See also the European Commission's (2006) report on "Entrepreneurship Education in Europe" and Oosterbeek et al. (2008) for an empirical attempt to evaluate the impact of entrepreneurship education.

${ }^{8}$ In support of this statement, note that Oosterbeek et al. (2008) find that a leading entrepreneurship education program has no effect on college students' intention to become an entrepreneur. Their empirical analysis is based on difference-in-differences methodology.

9 "The power of example to activate and channel behavior has been abundantly documented. ... One can get people to ... converse on particular topics, to be inquisitive or passive, to think innovatively or conventionally, and to engage in almost any course or action by having such conduct exemplified" (Bandura 1986: 206).
} 
entrepreneurially-inclined identity is similarly developed (cf. Halaby 2003; Johnson 2002; Mortimer and Lorence 1979). So if an individual's parents are his or her initial role models and thus have a seminal influence on the child's self-image across the lifespan, and if the parents are entrepreneurial, it is quite possible that their child will choose that sort of identity also (cf. Bandura 1977). ${ }^{11}$ This view is also in line with the labor economic literature on intergenerational transmission of labor market outcomes, i.e., income (cf. Solon 1999). Thereby, Björklund et al. (2007) emphasize that both nature and nurture are at play in the intergenerational transmission of socioeconomic status.

Once entered, the informal school environment, with its various social categories and expectations (e.g., nerds, jocks, or burnouts as described in Coleman (1961), along with the formal school philosophy geared toward producing "certain types of human beings" (Bloom 1987: 26) are additional critical influences on the development of identity. ${ }^{12}$ Based on interviews, Eckert (1995) for example found that the jocks' lives lie between the boundaries of the school and its extracurricular activities. This suggests that the influence of peers at school is more pronounces than neighborhood effects. It is largely how well one does at school, academically or socially, that determines one's future occupation and, thus, taken to its logical extreme, the welfare of all society. Therefore, we follow this line of reasoning and assume that the initial influence on identity originates with parents and that the self-image thus formed, even if only partially, will have an impact on the child's engagement with the school environment and how he or she interacts and is influenced by peers.

Assuming that children of school age are rather not aware of which occupation would ideally complement her skills and thus earn the highest future returns while nevertheless identities are formed that influence the future occupational choice, we will now

\footnotetext{
${ }^{10}$ However, it is important to note that independent research from the fields of developmental psychology and neuroscience emphasizes the role of early childhood experiences as well (cf. Heckman, 2006).

${ }^{11}$ This assumption is also in line with findings by the Harvard Center for Entrepreneurial History. Miller (1952) and also Neu and Gregory (1952) both find that the most influencing business men during in the period of the great American Industrialization from 1870-1910 came from landowning or entrepreneurial families.

12 "The people with whom one regularly associates, either through preference or imposition, delimit the behavioral patterns that will be repeatedly observed, and hence, learned most thoroughly" (Bandura 1986: $55)$.
} 
concentrate on the identity part of the occupational choice presented in Equation (1). In doing so, we follow sociological research by e.g., Halaby (2003); Johnson (2002),or Mortimer and Lorence (1979), and assume that the aggregate effects of experiences in the youth have the strongest influence on an individuals future occupational identity. To this end, we develop hypotheses and then analyze how an entrepreneurial identity is influenced by parents and peers.

\section{The Development of an Entrepreneurial Identity}

A child's identity and predilection for a certain occupation-entrepreneurial or notdepends on what he or she has experienced at home from her parents' identity and their working life. Or, as Marshall (1920) put it, "as years pass on, the child of the working man learns a great deal from what he sees and hears going on around him." Here, we follow the lead of Aldrich et al. (1998), Dunn and Holtz-Eakin (2000), and Hout and Rosen (2000) and assume that entrepreneurial parents leave an especially pronounced mark on their children due to "their ability to provide contact between their children (while the children are relatively young) and the business workplace. ... As the child receives continued exposure to the family business, he picks up, almost without realizing it, a working knowledge of how to run a business enterprise" (Lentz \& Laband 1990: 564). Recent literature (cf. Dohmen et al. 2006) emphasizes that this also includes the intergenerational transmission of risk attitudes. This leads to our first hypothesis.

Hypothesis 1: Children are likely to adopt their parents' identity. Hence, having parents who are entrepreneurs should have a positive impact on the child's intention to become an entrepreneur as well.

Children are also heavily influenced by their peers' ideas about the ideal job (Banduras 1977). Let us assume that a certain fraction of a child's peers think of themselves and others as future entrepreneurs, although perhaps not in that exact terminology at this point. These peers think it would be "cool" to be your own boss, run your own business, and not have to take orders from anyone else. These particular children are quite likely very intelligent, adventurous, possibly bored with a school curriculum targeted at slower and more docile children. They are in short, fun to hang out with, and "leaders of the pack." And leadership, argues Baumol (1968), is one of the major ingredients for 
entrepreneurial success. ${ }^{13}$ Since these entrepreneurial peers are so attractive and fun to be around, it is plausible that they could have a great deal of influence on other children's identity choice. Accordingly, the second hypothesis has to do with peer groups.

Hypothesis 2: The larger the leading entrepreneurial peer group, the more pronounced an individual's entrepreneurial identity will be. Hence, the size of the entrepreneurial peer group should have a positive impact on the child's intention to become an entrepreneur.

In the following section, we put these two hypotheses to an empirical test in an attempt to discover whether our theoretical arguments that parents and peers play an important role in the development of an entrepreneurial identity hold true.

\section{Data}

We use data from the 2006 cycle of the Programme for International Student Assessment (PISA) (OECD, 2007a, 2007b) to empirically test our two hypotheses. The main objective of PISA is to assess the scientific, mathematical, and reading literacy of the student population in each of 57 participating countries. PISA is a representative sample of all 15-year-olds enrolled in school. Thus, in most of the countries assessed, the target population comprises young people near the end of their compulsory schooling. As for the PISA sampling procedure, most countries employ a two-stage sampling technique. The first stage draws a (usually stratified) random sample of schools in which 15-year-old students are enrolled. In the second stage, a random sample of 35 of the 15-year-old students in each of these schools is drawn, with each 15-year-old student in a school having an equal chance of being selected.

In addition to the performance tests, students provide detailed information on their personal characteristics and family backgrounds. Moreover, school principals report details on their schools' resource endowments and institutional settings.

\footnotetext{
${ }^{13}$ The entrepreneur's job is "to locate new ideas and to put them into effect. He must lead, perhaps even inspire; he cannot allow things to get into a rut and for him today's practice is never good enough for tomorrow. ... He is the individual who exercises what in the business literature is called 'leadership"' (Baumol 1968: 65).
} 
Our main variable of interest is the students' response to the question of what kind of job they intend to have when they are about 30 years old. Students are asked to write down the job title, which is then given a four-digit ISCO-88 code (International Standard Classification of Occupations; ILO 1990). Table 1a contains descriptive statistics of the students' intended occupations at age 30 . One caveat applies here: This variable measures students' intentions to become entrepreneurs, and thus might not be a good predictor for his or her actual future occupational choice. However, following sociological research based on longitudinal data, these intentions are a strong indicator of future occupational intentions (cf. Halaby 2003; Johnson 2002; Mortimer and Lorence 1979).

We argue that, at the age of 15 , students have, for the most part, not collected any labor market experiences, and hence do not yet know whether they possess the necessary abilities to become a successful entrepreneur. In other words, we assume that their intentions to become an entrepreneur are not driven by ability considerations, but rather based on their identity which is, at that stage, fully developed, and, as outlined above, influenced by parents' and peers' entrepreneurial identity.

The students also provide information on their mother's and father's occupation, which again is given a four digit ISCO- 88 code (see Table $1 \mathrm{~b}$ for descriptive statistics).

For both the students' intended occupations and the parents' actual occupations we construct a dummy variable that takes the value 1 if the occupation is entrepreneurial, and 0 otherwise. Moreover, we employ two different definitions of an entrepreneurial occupation, as shown in Table 1c: (i) a broad definition of entrepreneurial occupation containing all ISCO-88 codes starting with $13 \mathrm{xx}$ (Definition 1), and (ii) a more restrictive definition excluding agriculture, forestry, and fishing professions (Definition 2). All codes reflect occupations that are related to running small enterprises. Indeed, running a small business is commonly regarded as a good proxy for entrepreneurship (cf. Parker 2009). 
Table 1a. Descriptive statistics: percentage of students intending to be in an entrepreneurial occupation at age 30

\begin{tabular}{|c|c|c|c|c|c|c|c|c|c|c|c|c|c|c|}
\hline & 1300 & 1310 & 1311 & 1312 & 1313 & 1314 & 1315 & 1316 & 1317 & 1318 & 1319 & $\begin{array}{l}\text { Any } \\
13 x x\end{array}$ & $\begin{array}{c}13 \times x \\
\text { without } \\
1311 \\
\end{array}$ & $\begin{array}{c}\% \\
\text { missing }\end{array}$ \\
\hline AUS & $0.30 \%$ & $1.75 \%$ & $0.03 \%$ & $0.06 \%$ & $0.05 \%$ & $0.20 \%$ & $0.31 \%$ & & $0.02 \%$ & $0.08 \%$ & $0.41 \%$ & $3.21 \%$ & $3.17 \%$ & $13.45 \%$ \\
\hline AUT & $0.52 \%$ & & & & $0.02 \%$ & $0.09 \%$ & $0.55 \%$ & & $0.03 \%$ & $0.15 \%$ & $0.20 \%$ & $1.56 \%$ & $1.56 \%$ & $17.63 \%$ \\
\hline BEL & & $0.35 \%$ & $0.15 \%$ & & $0.20 \%$ & $0.58 \%$ & $0.66 \%$ & $0.03 \%$ & $0.03 \%$ & & $1.47 \%$ & $3.47 \%$ & $3.31 \%$ & $9.57 \%$ \\
\hline CAN & & & $0.40 \%$ & $0.02 \%$ & $0.26 \%$ & $0.17 \%$ & $0.23 \%$ & $0.04 \%$ & $0.04 \%$ & $0.05 \%$ & $0.06 \%$ & $1.27 \%$ & $0.87 \%$ & $5.04 \%$ \\
\hline CHE & & & & & & & & & & & & $0.00 \%$ & $0.00 \%$ & $9.32 \%$ \\
\hline CZE & & $5.40 \%$ & $0.33 \%$ & $0.15 \%$ & $0.02 \%$ & $0.14 \%$ & $0.80 \%$ & $0.07 \%$ & $0.07 \%$ & & $1.10 \%$ & $8.09 \%$ & $7.76 \%$ & $20.86 \%$ \\
\hline DEU & $0.05 \%$ & $0.40 \%$ & $0.02 \%$ & & & $0.05 \%$ & $0.15 \%$ & $0.03 \%$ & $0.01 \%$ & & $0.21 \%$ & $0.92 \%$ & $0.90 \%$ & $21.01 \%$ \\
\hline DNK & & & & & & $0.55 \%$ & $0.08 \%$ & & $0.03 \%$ & & $0.07 \%$ & $0.73 \%$ & $0.73 \%$ & $6.33 \%$ \\
\hline ESP & $0.82 \%$ & $0.69 \%$ & $0.01 \%$ & & $0.04 \%$ & $0.01 \%$ & $0.16 \%$ & & & & $0.05 \%$ & $1.79 \%$ & $1.78 \%$ & $20.02 \%$ \\
\hline FIN & & $1.06 \%$ & & & $0.05 \%$ & $0.07 \%$ & $0.17 \%$ & $0.04 \%$ & & & $0.21 \%$ & $1.60 \%$ & $1.60 \%$ & $9.55 \%$ \\
\hline GBR & $0.12 \%$ & $1.27 \%$ & $0.06 \%$ & $0.03 \%$ & $0.29 \%$ & $0.48 \%$ & $0.38 \%$ & $0.04 \%$ & $0.17 \%$ & $0.17 \%$ & $0.22 \%$ & $3.21 \%$ & $3.15 \%$ & $6.75 \%$ \\
\hline GRC & $0.06 \%$ & $0.39 \%$ & $0.02 \%$ & $0.05 \%$ & $0.25 \%$ & $0.54 \%$ & $0.28 \%$ & & $0.02 \%$ & $0.04 \%$ & $0.22 \%$ & $1.88 \%$ & $1.86 \%$ & $20.52 \%$ \\
\hline HUN & & & & & & $0.51 \%$ & $0.21 \%$ & & $0.03 \%$ & $0.03 \%$ & $0.51 \%$ & $1.28 \%$ & $1.28 \%$ & $18.37 \%$ \\
\hline IRL & & $1.78 \%$ & $0.09 \%$ & & $0.19 \%$ & $0.22 \%$ & $0.33 \%$ & $0.07 \%$ & $0.02 \%$ & $0.35 \%$ & $0.19 \%$ & $3.25 \%$ & $3.15 \%$ & $10.42 \%$ \\
\hline ISL & $0.03 \%$ & $0.85 \%$ & & & & $0.03 \%$ & $0.09 \%$ & & & & & $0.99 \%$ & $0.99 \%$ & $23.68 \%$ \\
\hline ITA & $0.10 \%$ & $1.12 \%$ & $0.10 \%$ & $0.04 \%$ & $0.17 \%$ & $1.91 \%$ & $0.52 \%$ & $0.00 \%$ & $0.03 \%$ & $0.06 \%$ & $0.23 \%$ & $4.29 \%$ & $4.19 \%$ & $7.96 \%$ \\
\hline JPN & $0.71 \%$ & & & & & & & & & & & $0.71 \%$ & $0.71 \%$ & $13.73 \%$ \\
\hline KOR & & $2.32 \%$ & $0.02 \%$ & $0.02 \%$ & $0.08 \%$ & $0.81 \%$ & $0.20 \%$ & $0.06 \%$ & $0.02 \%$ & $0.02 \%$ & & $3.54 \%$ & $3.52 \%$ & $3.44 \%$ \\
\hline LUX & & $1.33 \%$ & & $0.02 \%$ & & $0.14 \%$ & $0.76 \%$ & $0.02 \%$ & $0.05 \%$ & $0.02 \%$ & & $2.34 \%$ & $2.34 \%$ & $7.47 \%$ \\
\hline MEX & $0.40 \%$ & $0.03 \%$ & $0.02 \%$ & $0.01 \%$ & $0.03 \%$ & $0.30 \%$ & $0.19 \%$ & $0.02 \%$ & $0.00 \%$ & & $0.01 \%$ & $1.01 \%$ & $0.99 \%$ & $16.92 \%$ \\
\hline NLD & & $0.24 \%$ & $0.61 \%$ & $0.27 \%$ & $0.23 \%$ & $2.29 \%$ & $2.19 \%$ & $0.06 \%$ & $0.10 \%$ & & $1.11 \%$ & $7.11 \%$ & $6.50 \%$ & $3.70 \%$ \\
\hline NOR & $0.23 \%$ & $0.62 \%$ & $0.02 \%$ & & $0.03 \%$ & $0.55 \%$ & $0.43 \%$ & $0.09 \%$ & & $0.06 \%$ & & $2.03 \%$ & $2.01 \%$ & $19.07 \%$ \\
\hline NZL & & $2.74 \%$ & $0.66 \%$ & & $0.03 \%$ & $0.44 \%$ & $0.92 \%$ & & & $0.11 \%$ & $0.10 \%$ & $5.00 \%$ & $4.34 \%$ & $12.26 \%$ \\
\hline POL & & & & & $0.07 \%$ & $0.09 \%$ & $0.36 \%$ & $0.04 \%$ & & & $0.91 \%$ & $1.46 \%$ & $1.46 \%$ & $12.72 \%$ \\
\hline PRT & & $0.03 \%$ & & & & & $0.14 \%$ & & & & $0.02 \%$ & $0.19 \%$ & $0.19 \%$ & $4.04 \%$ \\
\hline SVK & $0.24 \%$ & $3.52 \%$ & $0.03 \%$ & $0.02 \%$ & $0.15 \%$ & $1.42 \%$ & $0.17 \%$ & $0.03 \%$ & $0.17 \%$ & & $0.02 \%$ & $5.78 \%$ & $5.74 \%$ & $12.77 \%$ \\
\hline SWE & & $2.49 \%$ & $0.07 \%$ & $0.02 \%$ & $0.15 \%$ & $0.96 \%$ & $0.50 \%$ & $0.02 \%$ & $0.14 \%$ & & $0.25 \%$ & $4.60 \%$ & $4.53 \%$ & $8.58 \%$ \\
\hline TUR & $0.34 \%$ & & & $0.04 \%$ & $0.35 \%$ & $1.44 \%$ & $0.17 \%$ & $0.02 \%$ & & $0.42 \%$ & $0.05 \%$ & $2.83 \%$ & $2.83 \%$ & $20.44 \%$ \\
\hline USA & & & $0.02 \%$ & & $0.08 \%$ & $0.31 \%$ & $0.40 \%$ & & $0.12 \%$ & $0.28 \%$ & $1.57 \%$ & $2.77 \%$ & $2.75 \%$ & $7.19 \%$ \\
\hline All $15 \mathrm{cnt}$ & $0.18 \%$ & $0.96 \%$ & $0.11 \%$ & $0.03 \%$ & $0.11 \%$ & $0.64 \%$ & $0.46 \%$ & $0.02 \%$ & $0.04 \%$ & $0.08 \%$ & $0.37 \%$ & $3.00 \%$ & $2.89 \%$ & \\
\hline All $28 \mathrm{cnt}$ & $0.14 \%$ & $0.99 \%$ & $0.09 \%$ & $0.02 \%$ & $0.11 \%$ & $0.51 \%$ & $0.40 \%$ & $0.02 \%$ & $0.04 \%$ & $0.07 \%$ & $0.32 \%$ & $2.71 \%$ & $2.62 \%$ & \\
\hline
\end{tabular}


Table 1b. percentage of students intending to be in an entrepreneurial occupation, and percentage of students with parents in an entrepreneurial occupation, by country

\begin{tabular}{|c|c|c|c|c|c|c|}
\hline & \multicolumn{4}{|c|}{ Percentage of students who report that... } & \multicolumn{2}{|c|}{$\begin{array}{l}\text { Percentage of missing } \\
\text { values }\end{array}$} \\
\hline & $\begin{array}{c}\text { either parent } \\
\text { is an } \\
\text { entrepreneur } \\
\text { (definition 1) }\end{array}$ & $\begin{array}{c}\text { either parent } \\
\text { is an } \\
\text { entrepreneur } \\
\text { (definition 2) }\end{array}$ & $\begin{array}{l}\text { they intend to } \\
\text { be in an } \\
\text { entrepreneuria } \\
\text { I occupation at } \\
\text { age } 30 \\
\text { (definition 1) }\end{array}$ & $\begin{array}{l}\text { they intend to } \\
\text { be in an } \\
\text { entrepreneuri } \\
\text { al occupation } \\
\text { at age } 30 \\
\text { (definition 2) }\end{array}$ & $\begin{array}{c}\text { parents' } \\
\text { occupation }\end{array}$ & $\begin{array}{c}\text { students' } \\
\text { intended } \\
\text { occupation }\end{array}$ \\
\hline AUS & $10.92 \%$ & $10.69 \%$ & $3.21 \%$ & $3.17 \%$ & $1.94 \%$ & $13.45 \%$ \\
\hline AUT & $7.43 \%$ & $7.40 \%$ & $1.56 \%$ & $1.56 \%$ & $0.80 \%$ & $17.63 \%$ \\
\hline BEL & $9.69 \%$ & $9.33 \%$ & $3.47 \%$ & $3.31 \%$ & $1.09 \%$ & $9.57 \%$ \\
\hline CAN & $9.62 \%$ & $6.69 \%$ & $1.27 \%$ & $0.87 \%$ & $1.58 \%$ & $5.04 \%$ \\
\hline CZE & $21.16 \%$ & $20.56 \%$ & $8.09 \%$ & $7.76 \%$ & $1.60 \%$ & $20.86 \%$ \\
\hline DEU & $4.18 \%$ & $4.16 \%$ & $0.92 \%$ & $0.90 \%$ & $5.17 \%$ & $21.01 \%$ \\
\hline DNK & $2.30 \%$ & $2.19 \%$ & $0.73 \%$ & $0.73 \%$ & $1.57 \%$ & $6.33 \%$ \\
\hline ESP & $7.30 \%$ & $7.28 \%$ & $1.79 \%$ & $1.78 \%$ & $0.71 \%$ & $20.02 \%$ \\
\hline FIN & $4.20 \%$ & $4.20 \%$ & $1.61 \%$ & $1.61 \%$ & $0.81 \%$ & $9.55 \%$ \\
\hline GBR & $13.70 \%$ & $13.46 \%$ & $3.21 \%$ & $3.15 \%$ & $3.92 \%$ & $6.75 \%$ \\
\hline GRC & $19.36 \%$ & $19.06 \%$ & $1.88 \%$ & $1.86 \%$ & $1.01 \%$ & $20.52 \%$ \\
\hline HUN & $4.37 \%$ & $4.15 \%$ & $1.28 \%$ & $1.28 \%$ & $1.15 \%$ & $18.37 \%$ \\
\hline IRL & $13.72 \%$ & $13.28 \%$ & $3.25 \%$ & $3.15 \%$ & $2.79 \%$ & $10.42 \%$ \\
\hline ISL & $9.27 \%$ & $9.23 \%$ & $1.00 \%$ & $1.00 \%$ & $2.51 \%$ & $23.68 \%$ \\
\hline ITA & $17.80 \%$ & $17.01 \%$ & $4.29 \%$ & $4.19 \%$ & $0.79 \%$ & $7.96 \%$ \\
\hline JPN & $7.23 \%$ & $7.23 \%$ & $0.71 \%$ & $0.71 \%$ & $2.67 \%$ & $13.73 \%$ \\
\hline KOR & $29.24 \%$ & $28.87 \%$ & $3.54 \%$ & $3.52 \%$ & $0.53 \%$ & $3.44 \%$ \\
\hline LUX & $8.87 \%$ & $8.70 \%$ & $2.36 \%$ & $2.36 \%$ & $1.35 \%$ & $7.47 \%$ \\
\hline MEX & $3.30 \%$ & $3.27 \%$ & $1.01 \%$ & $0.99 \%$ & $1.37 \%$ & $16.92 \%$ \\
\hline NLD & $12.60 \%$ & $10.58 \%$ & $7.11 \%$ & $6.50 \%$ & $1.29 \%$ & $3.70 \%$ \\
\hline NOR & $11.40 \%$ & $11.21 \%$ & $2.03 \%$ & $2.01 \%$ & $2.71 \%$ & $19.07 \%$ \\
\hline NZL & $17.75 \%$ & $14.43 \%$ & $5.00 \%$ & $4.34 \%$ & $2.09 \%$ & $12.26 \%$ \\
\hline POL & $9.60 \%$ & $9.54 \%$ & $1.46 \%$ & $1.46 \%$ & $0.81 \%$ & $12.72 \%$ \\
\hline PRT & $2.26 \%$ & $2.26 \%$ & $0.19 \%$ & $0.19 \%$ & $0.48 \%$ & $4.04 \%$ \\
\hline SVK & $6.02 \%$ & $5.74 \%$ & $5.78 \%$ & $5.75 \%$ & $0.77 \%$ & $12.77 \%$ \\
\hline SWE & $16.78 \%$ & $16.04 \%$ & $4.60 \%$ & $4.53 \%$ & $1.14 \%$ & $8.58 \%$ \\
\hline TUR & $16.18 \%$ & $16.18 \%$ & $2.83 \%$ & $2.83 \%$ & $0.77 \%$ & $20.44 \%$ \\
\hline USA & $9.52 \%$ & $9.27 \%$ & $2.77 \%$ & $2.75 \%$ & $3.54 \%$ & $7.19 \%$ \\
\hline All 28 & $10.96 \%$ & $10.46 \%$ & $2.71 \%$ & $2.62 \%$ & & \\
\hline All 15 & $12.24 \%$ & $11.68 \%$ & $3.00 \%$ & $2.89 \%$ & & \\
\hline
\end{tabular}

Note: based on PISA2006, not imputed data, weighted by the inverse of students' sampling probabilities 
Table 1c. Classification of entrepreneurial occupations according to definition 1 and 2

\begin{tabular}{|c|c|c|c|}
\hline $\begin{array}{l}\text { ISCO-88 } \\
\text { Code }\end{array}$ & & $\begin{array}{l}\text { Definition } \\
1\end{array}$ & $\begin{array}{l}\text { Definition } \\
2\end{array}$ \\
\hline 1300 & [SMALL ENTERPRISE] GENERAL MANAGERS & $\checkmark$ & $\checkmark$ \\
\hline 1310 & $\begin{array}{l}\text { [SMALL ENTERPRISE] GENERAL MANAGERS [incl. } \\
\text { Businessman, Trader, Manager nfs] }\end{array}$ & $\checkmark$ & $\checkmark$ \\
\hline 1311 & $\begin{array}{l}\text { [Small enterprise] General managers agriculture, forestry } \\
\& \text { fishing [incl. Farm Manager, Self-employed Farmer } \\
\text { with personnel] }\end{array}$ & $\checkmark$ & \\
\hline 1312 & [Small enterprise] General managers manufacturing & $\checkmark$ & $\checkmark$ \\
\hline 1313 & $\begin{array}{l}\text { [Small enterprise] General managers construction [incl. } \\
\text { Building Contractor] }\end{array}$ & $\checkmark$ & $\checkmark$ \\
\hline 1314 & $\begin{array}{l}\text { [Small enterprise] General managers wholesale \& retail } \\
\text { trade [incl. Shop Owner/Manager, Retail } \\
\text { Owner/Manager, Merchant] }\end{array}$ & $\checkmark$ & $\checkmark$ \\
\hline 1315 & 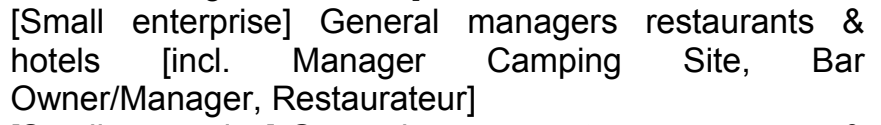 & $\checkmark$ & $\checkmark$ \\
\hline 1316 & $\begin{array}{l}\text { [Small enterprise] General managers transp., storage, \& } \\
\text { communications [incl. Owner Small Transport Company] }\end{array}$ & $\checkmark$ & $\checkmark$ \\
\hline 1317 & $\begin{array}{l}\text { [Small enterprise] General managers business services } \\
\text { [incl. Manager Insurance Agency] }\end{array}$ & $\checkmark$ & $\checkmark$ \\
\hline 1318 & $\begin{array}{l}\text { [Small enterprise] General managers personal care, } \\
\text { cleaning, etc. services [incl. Owner Laundry] }\end{array}$ & $\checkmark$ & $\checkmark$ \\
\hline 1319 & $\begin{array}{l}\text { [Small enterprise] General managers nec [incl. Manager } \\
\text { Travel Agency, Manager Fitness Center, Garage Owner] }\end{array}$ & $\checkmark$ & $\checkmark$ \\
\hline
\end{tabular}

Our reason for making this distinction is that entrepreneurship in agriculture differs from that in other fields with respect to the share of individuals who run their own business. Moreover, the importance of agriculture differs across countries. Due to tradition and institutions, firm succession by children - often the son-is more common in agriculture than in other fields.

To measure peer effects, we calculate the share of students intending to be in an entrepreneurial occupation at the age of 30 at the school level. ${ }^{14}$ Table $1 \mathrm{~d}$ provides descriptive statistics on this variable, as well as the percentage of missing values.

\footnotetext{
${ }^{14}$ More precisely, this share is calculated after excluding individual $\mathrm{i}$, and hence referred to as $\overline{\mathrm{ExOCC}}_{- \text {isc }}$ peers in our estimated regression equations shown below.
} 
Table 1d. Descriptive statistics for the size of the entrepreneurial peer group, by country

\begin{tabular}{|c|c|c|c|c|}
\hline & "Minimum & "Maximum & Mean & "Std. Deviation \\
\hline AUS & 0.000 & 0.321 & 0.031 & 0.032 \\
\hline AUT & 0.000 & 0.500 & 0.014 & 0.042 \\
\hline BEL & 0.000 & 0.341 & 0.034 & 0.044 \\
\hline CAN & 0.000 & 0.202 & 0.012 & 0.025 \\
\hline CZE & 0.000 & 0.364 & 0.075 & 0.075 \\
\hline DEU & 0.000 & 0.143 & 0.009 & 0.024 \\
\hline DNK & 0.000 & 0.218 & 0.007 & 0.022 \\
\hline ESP & 0.000 & 0.192 & 0.017 & 0.030 \\
\hline FIN & 0.000 & 0.101 & 0.016 & 0.024 \\
\hline GBR & 0.000 & 0.289 & 0.031 & 0.044 \\
\hline GRC & 0.000 & 0.528 & 0.018 & 0.036 \\
\hline HUN & 0.000 & 0.177 & 0.012 & 0.031 \\
\hline IRL & 0.000 & 0.230 & 0.031 & 0.039 \\
\hline ISL & 0.000 & 0.137 & 0.010 & 0.020 \\
\hline ITA & 0.000 & 0.571 & 0.041 & 0.054 \\
\hline JPN & 0.000 & 0.115 & 0.007 & 0.018 \\
\hline KOR & 0.000 & 0.242 & 0.035 & 0.042 \\
\hline LUX & 0.000 & 0.589 & 0.023 & 0.035 \\
\hline MEX & 0.000 & 0.326 & 0.009 & 0.026 \\
\hline NLD & 0.000 & 0.238 & 0.068 & 0.055 \\
\hline NOR & 0.000 & 0.174 & 0.020 & 0.032 \\
\hline NZL & 0.000 & 0.188 & 0.048 & 0.046 \\
\hline POL & 0.000 & 0.504 & 0.014 & 0.023 \\
\hline PRT & 0.000 & 0.068 & 0.002 & 0.009 \\
\hline SVK & 0.000 & 0.590 & 0.055 & 0.063 \\
\hline SWE & 0.000 & 0.334 & 0.044 & 0.044 \\
\hline TUR & 0.000 & 0.179 & 0.028 & 0.038 \\
\hline USA & 0.000 & 0.250 & 0.027 & 0.035 \\
\hline All $28 \mathrm{cnt}$ & 0.000 & 0.590 & 0.026 & 0.043 \\
\hline All $15 \mathrm{cnt}$ & 0.000 & 0.571 & 0.028 & 0.041 \\
\hline
\end{tabular}

Note: the size of the entrepreneurial peer group is measured as the share of students in one's school intending to be entrepreneurs at age 30 (calculated after excluding individual i)

based on entrepreneurship definition 1

For the purpose of the following analyses, observations with missing values for any of these three variables are deleted. Our dataset thus contains 204,074 students from 28 of the 30 OECD countries. Switzerland is excluded because no student from that country reported intending to be in any kind of an entrepreneurial occupation at age 30 . As we control in most specifications for a large number of background variables to minimize potential biases from omitted variables at the school level, we also dropped France from 
the sample because no school-level background information is provided for any of the schools sampled in this country.

Since the PISA database provides a rich set of control variables, we are able to control for other influencing factors at the individual or school level. In the first step, we entered a large set of control variables at the student and school level in our model. Then, using Wald tests, we tested which variables did not enter the regression equation jointly significantly, excluded them, and were thus left with a considerably smaller set of controls. Among the student and family background variables, there is information on the student's gender, three indicators for the student's immigrant status (namely, native, first and second generation immigrant students), and, finally, the scores from the student's performance in science and mathematics. Regarding family background, we control for an indicator of family wealth as well as parents' educational attainment.

At the school level, we include four dummies as controls for the size of the community where the school is located, along with several aggregated measures of the schools' socioeconomic composition. We also control for learning time in regular lessons

provided to the student. ${ }^{15}$ Like any survey data set, the PISA dataset contains missing values. Although the percentage of missing values is minor for almost any single control variable in our model, deletion of all student observations with a missing value on at least one variable would mean a severe reduction in sample size. We thus include missing dummies in all regressions and set the missing explanatory variables to zero if the respective variable is categorical, or replace the missing value by the weighted school (country) mean of the respective variable if it is continuous.

\section{Econometric Model}

To discover what determines a student's intention of being in an entrepreneurial occupation at age 30 , we estimate cross-country regressions controlling for different sets of background variables at the student and school levels. We include country dummies to account for unobserved heterogeneity across countries.

\footnotetext{
${ }^{15}$ See Fuchs and Wößmann (2007) for an overview of common controls in empirical analysis based on PISA data.
} 
In particular, we estimate the following probit regression equation where the outcome variable $E x O C C_{i s c}$ is the conditional probability of student $i$ in school $s$ and country $c$ intending to be in an entrepreneurial occupation at age 30

$$
\begin{aligned}
& P\left(E_{\text {ExOCC }}=1\right)=\Phi\left(\alpha \cdot O C C_{i s c}^{\text {parents }}+\beta \cdot \overline{E x O C C}_{\text {-isc }}^{\text {peers }}+X\right) \\
& \text { where } X \equiv B_{i s c} \gamma+R_{s c} \delta+I_{s c} \theta+\varphi_{c} \cdot C_{c} \\
& B_{i s c} \text { : vector of family background variables } \\
& R_{s c}: \text { vector of school resource variables } \\
& I_{s c}: \text { vector of institutional characteristics of school } s \text { in country } c \\
& C_{c}: \text { vector of country dummies }
\end{aligned}
$$

Our main interest lies in the parameters $\alpha$, the coefficient on parents' actual entrepreneurial activity ( $O C C_{i s c}{ }^{\text {parents }}$, Hypothesis 1$)$, and $\beta$, the coefficient on the share of students at school intending to be in an entrepreneurial occupation at age 30 , $\left(\overline{\operatorname{ExOCC}}_{-i s c}^{\text {peers }}\right.$, Hypothesis 2).

To account for the two-stage survey sampling design, we use clustering robust linear regression, where standard errors are clustered at the school level (cf. Moulton 1986; Deaton 1997: 74-78). Furthermore, we weight each student by the inverse of his or her sampling probability (DuMouchel \& Duncan 1983; Wooldridge 2001). In all crosscountry regressions, we also give each country equal weight in the estimation.

To be able to interpret the coefficient $\beta$ on the share of entrepreneurial peers at school as a true peer effect, we need to go beyond a cross-sectional regression analysis and show that the observed partial correlation between an individual's entrepreneurial intention and her peers' entrepreneurial intention is in fact due to some form of social interaction (Manski 1995). Manski (1995) identifies two broad forms of social interaction. In the first, youth behavior is influenced by the prevalence of that behavior in the group (endogenous effects). In our model of occupational choice, this would mean that an individual's intention to become an entrepreneur is influenced by her peers' intentions to become entrepreneurs. In the second form of social interaction, youth behavior is influenced by exogenous characteristics of the youth's reference group. In our model, this 
would mean that an individual's intention to become an entrepreneur is influenced by her peers' background characteristics (exogenous or contextual effects).

Manski (1995) raises the possibility of spurious estimates of peer-group effects that may be erroneously interpreted as true endogenous or contextual effects: the so-called correlated effects. These can arise when youths in the same reference group express the same occupational intentions because they share a common set of unobserved characteristics. Students and their peers are very likely to be subject to the same influences when they attend the same school, influences both observed and unobserved by an econometrician. To minimize the bias from the observed shared influences, we include numerous control variables in the regression equation (see the term $X$ in Equation (4)). We address the problem of unobserved shared influences at the school level by means of an instrumental variable probit model. In particular, we use the share of students with entrepreneurial parents as an instrument for the share of students with entrepreneurial intentions at school level. The identifying assumption is that there are no exogenous effects, i.e., that the share of parents at school who are entrepreneurs does not have a direct effect on an individual's intention to become an entrepreneur.

We use schools as the relevant sphere for interaction with the peer group (as opposed to neighborhoods, for instance). Following Gaviria and Raphael (2001), we argue that since students interact primarily during school hours, the estimated effects are more likely to reflect the influence of peers rather than the influence of peer background factors. In Manski's (1995) terms, we are assuming that there are no contextual effects. Our assumption is that any influence peers might have on students' entrepreneurial intentions is through the peers' own entrepreneurial intentions. The predominance of endogenous peer effects over contextual effects is also found in studies on the smoking behavior of adolescents (Norton et al. 1998) or on adolescent overweight (Trogdon et al. 2008).

Although our instrumental variable approach addresses the problem of correlated effects, it does not address the issue of endogenous sorting of households across schools. This sorting could arise if entrepreneurial parents sort across regions and, eventually, schools according to their willingness to invest in their children's future. However, this should not be a predominant problem in the case of entrepreneurial parents, as it is most likely 
that entrepreneurs are regionally "sticky" (Feldman 2001), meaning that, in general, entrepreneurs are either life-long residents of the region (Michelacci and Silva, 2007) or have lived there for at least several years (Greene et al., 2008; Keeble and Walker, 1994; Saxenian, 1999). Nevertheless, we reinvestigate this issue in the robustness checks.

\section{Results}

We report the results from all probit and instrumental variables probit regressions reporting the form of marginal effects at the sample mean.

Results: Basic probit and instrumental variables probit model

Table 2 contains the results of a cross-country probit regression of the students' intention of being in an entrepreneurial occupation at age 30 on a dummy indicating their parents' actual entrepreneurial occupation, as well as their school's share of students intending to be in an entrepreneurial occupation at age 30 .

Table 2 shows that, at the sample means of all regressors, the students' parents actually being in an entrepreneurial occupation increases the probability of the student intending to be in an entrepreneurial occupation at age 30 by between 2.8 and 3.3 percentage points (Hypothesis 1).

Moreover, the table shows that our results are robust to the inclusion of different sets of covariates, which does not change the sign and significance of the estimated marginal effects. 
Table 2. Cross-country regressions, marginal effects after probit and instrumental variables probit (at the sample mean)

\begin{tabular}{|c|c|c|c|c|c|c|c|c|c|}
\hline \multirow[t]{2}{*}{$\begin{array}{l}\text { Dependent } \\
\text { variable: }\end{array}$} & \multicolumn{3}{|c|}{$\begin{array}{l}\text { students' entrepreneurial intentions } \\
\text { (definition 1) }\end{array}$} & \multicolumn{3}{|c|}{$\begin{array}{l}\text { students' entrepreneurial intentions } \\
\text { (definition 2) }\end{array}$} & \multicolumn{3}{|c|}{$\begin{array}{l}\text { students' entrepreneurial intentions } \\
\text { (definition 2) }\end{array}$} \\
\hline & (1) & $(2)$ & (3) & $(4)$ & $(5)$ & $(6)$ & $(7)$ & $(8)$ & $(9)$ \\
\hline either parent is an & $0.033^{* * *}$ & $0.029^{* * *}$ & $0.029^{* * *}$ & $0.032^{* * *}$ & $0.028^{* * *}$ & $0.028^{* * *}$ & & & \\
\hline $\begin{array}{l}\text { entrepreneur } \\
\text { (definition 1) }\end{array}$ & $(0.002)$ & $(0.002)$ & $(0.002)$ & $(0.002)$ & $(0.002)$ & $(0.002)$ & & & \\
\hline size of the & $0.120^{* * *}$ & $0.106^{* * *}$ & $0.240^{* * *}$ & $0.117^{* * *}$ & $0.103^{* * *}$ & $0.209^{* * *}$ & & & \\
\hline $\begin{array}{l}\text { entrepreneurial peer } \\
\text { group (definition } 1 \text { ) }\end{array}$ & $(0.009)$ & $(0.009)$ & $(0.046)$ & $(0.009)$ & $(0.009)$ & $(0.047)$ & & & \\
\hline $\begin{array}{l}\text { either parent is an } \\
\text { entrepreneur }\end{array}$ & & & & & & & $\begin{array}{l}0.034^{* * *} \\
(0.002)\end{array}$ & & \\
\hline (definition 2) & & & & & & & & $(0.002)$ & $(0.002)$ \\
\hline size of the & & & & & & & $0.119^{* * *}$ & $0.104^{* * *}$ & $0.226^{* * *}$ \\
\hline $\begin{array}{l}\text { entrepreneurial peer } \\
\text { group (definition 2) }\end{array}$ & & & & & & & $(0.009)$ & $(0.009)$ & $(0.046)$ \\
\hline $\begin{array}{l}\text { Background } \\
\text { variables }\end{array}$ & no & yes & yes & no & yes & yes & no & yes & yes \\
\hline Observations & 204,074 & 204,074 & 204,074 & 204,074 & 204,074 & 204,074 & 204,074 & 204,074 & 204,074 \\
\hline Countries & 28 & 28 & 28 & 28 & 28 & 28 & 28 & 28 & 28 \\
\hline $\begin{array}{l}\text { Peer group variable } \\
\text { instrumented }\end{array}$ & no & no & yes & no & no & yes & no & no & yes \\
\hline
\end{tabular}

Notes: Standard errors in parentheses; all models contain country fixed effects; each country is given equal weight

* significant at $10 \% ; * *$ significant at $5 \%$; ** significant at $1 \%$

In columns (3), (6) and (9), the size of the entrepreneurial peer group instrumented by share of parents at school that are entrepreneurs 
We can also conclude from this table that the results are insensitive to the definition of entrepreneurial occupation used, i.e., we rule out the possibility that a correlation between parents' actual entrepreneurial occupation and a child's intended entrepreneurial occupation is driven simply by different countries having different shares of employment in the agricultural sector, where, due to a possibly more traditional farm ownership succession, the impact of parents' occupation on one's own intended occupation may be stronger. In the following, we therefore restrict ourselves to Definition 1, the broader definition of an entrepreneurial occupation that includes the agricultural sector.

Table 2 also contains the estimation results of our instrumental variables probit regression. We instrumented the size of the entrepreneurial peer group with the share of students at school who have entrepreneurial parents, including a full set of control variables in our basic model. The marginal effect of our peer group variable is highly positively significant. Accounting for the endogeneity of the share of entrepreneurial peers at school, our IV estimates suggest that, evaluated at the sample means of all other regressors, an increase in the share of entrepreneurial peers at school by one standard deviation leads to an increase in the predicted probability of a student having entrepreneurial intentions by 1.4 percentage points ${ }^{16}$. Given that, on average in our sample only $2.7 \%$ of the students report having entrepreneurial intentions (cf. Table 1b), our estimated endogenous effect seems sizeable. If there was no endogeneity problem in our sample, and if the standard probit estimates reported in Table 2 could thus be interpreted causally, the results would suggest a somewhat smaller peer effect of 0.5 to 0.6 percentage points. We conclude that unobserved shared influences appear to lead to an underestimation of the endogenous effect in a standard probit model. Our interpretation, however, rests on the assumption that exogenous peer effects are absent.

With our instrumental variables approach, we get the same estimate for the effect of having entrepreneurial parents which results from the standard probit model. The effect amounts to, around 2.9 to 3.3 percentage points, evaluated at the sample means of all regressors. ${ }^{17}$

\footnotetext{
${ }^{16}$ We obtain this number by calculating the discrete difference between the predicted probability of a student who attends a school where the size of the entrepreneurial peer group is one standard deviation above the mean and who has average values on all other regressors, and the predicted probability of a student having average values on all regressors (including the size of the entrepreneurial peer group). This is different from the corresponding marginal effect evaluated at the sample means which we report in Table 2.

${ }^{17}$ We also estimated logit models and linear probability models to empirically test our two hypotheses. The resulting marginal effects were not significantly different from the probit marginal effects.
} 


\section{Robustness Checks}

\section{Alternative definition of the peer group}

Although our instrumental variable approach addresses the problem of correlated effects, there remains the potential econometric problem of endogenous sorting of students into schools. This sorting could arise if entrepreneurial parents sort across schools according to their willingness to invest in their children's future. As our main robustness check, we use a different definition of the peer group that allows us to estimate a model with school fixed effects: we define the peer group as students attending the same school and grade. One could argue that defining the peer group as students attending the same class would be more appropriate. However, PISA data do not contain information about classes. We thus follow Schneeweis and Winter-Ebmer (2007) and define the peer group as students attending the same grade level and school.

This alternative specification allows us to address the potential problem of endogenous sorting of students into schools, because we are now able to estimate our regression equation of interest using school fixed effects (in addition to the country fixed effects).

In this school fixed effects specification, we can only analyze schools with at least two different grade levels in the PISA data, and observations from schools with only one grade level had to be discarded. Moreover, we only used observations from the two most common grade levels in the respective country, i.e. from grade nine and ten in most countries, and dropped all other observations. Lastly, we restricted our sample to peer groups of at least five students per grade. Since we cannot use variation in peer group sizes between schools, this estimation strategy likely leads to a downward bias of the estimate for the peer effect.

We are thus left with a sample of 78,435 students from 14 countries $^{18}$ and 843 schools. This corresponds to a considerable reduction in sample size, but enables us to assess whether endogenous sorting of students into schools is potentially biasing our results (and in particular the estimate of our peer group effect).

Because of the incidental parameters problem that arises when estimating fixed effects in non-linear models when group sizes are small (Neyman and Scott, 1948), we do not estimate an IV probit regression model in this case. Instead, we estimate an instrumental variables linear probability

\footnotetext{
${ }^{18}$ The 14 countries are Australia, Austria, Belgium, Canada, the Czech Republic, Germany, Spain, Hungary, Italy, Luxembourg, the Netherlands, Portugal, Slovakia and Turkey.
} 
model with both country and school fixed effects. Similar to the approach taken above (the results of which are shown in Table 3), we instrument the share of entrepreneurial peers in the same school and grade with the share of peers with entrepreneurial parents in the same school and grade level.

Table 3 contains the results of this specification. Columns (1) and (2) differ only with respect to the control variables included. Column (1) does not contain any control variables besides the student's parents' entrepreneurial status, our measure of the peer group, and school and country fixed effects. In addition to that, the specification shown in column (2) controls for a number of individual and family background variables. ${ }^{19}$ In the specification without controls (column (1)), we find significant effects for both parents' entrepreneurial status and for the size of the entrepreneurial peer group. The effect of parents' entrepreneurial status is significant in both specifications, amounting to 5.2 percentage points. The results from our linear probability model in columns (1) and (2) suggest an estimate for the peer group effect of 0.8 and 0.9 percentage points for a one standard deviation increase in the share of peers in the same grade and school. Our IV estimate (cf. column (3)) suggests that the peer group effect is 3.5 percentage points for a one standard deviation increase in the share of peers in the same grade and school. However, the assumption that contextual effects are absent for students that attend the same grade level in a school is less likely fulfilled than for our basic peer group definition at school level (cf. Equation (4) and Table 2). The IV specification for this robustness check may thus overestimate the true peer effect. However, it seems plausible to argue that most of the endogeneity in the assignment of students to peer groups is due to endogenous sorting into schools, not grades within schools, such that the estimated peer effect from the (non IV) linear probability model (columns (1) and (2)) should provide a consistent estimate of the true peer effect. In this specification, however, we cannot disentangle whether we find endogenous or contextual peer effects.

\footnotetext{
${ }^{19}$ For details see the variables listed in Appendix A1 under the heading "Individual and family background variables"; all variables listed there except the grade dummies were used as control variables.
} 
Table 3. Robustness check 1: cross-country regressions, peer group defined as students attending the same grade and school (PISA 2006); linear regression and instrumental variables linear regression coefficients (linear probability model)

\begin{tabular}{llll}
\hline \hline & \multicolumn{1}{c}{ (1) } & (2) & (3) \\
\hline either parent is an entrepreneur (definition 1) & $0.058^{* * *}$ & $0.058^{\star * *}$ & $0.052^{\star * *}$ \\
& $(0.005)$ & $(0.005)$ & $(0.005)$ \\
size of the entrepreneurial peer group (definition 1) & $0.162^{* * *}$ & $0.152^{\star * *}$ & $0.670^{\star * *}$ \\
& $(0.056)$ & $(0.057)$ & $(0.039)$ \\
Background variables & no & yes & yes \\
Observations & 78,435 & 78,435 & 78,435 \\
Countries & 14 & 14 & 14 \\
Peer group variable instrumented & no & no & yes
\end{tabular}

Notes: Dependent variable; students' entrepreneurial intentions; standard errors in parentheses; models contain country and school fixed effects; each country is given equal weight; * significant at $10 \% ; * *$ significant at $5 \% ; * * *$ significant at $1 \%$

We conclude that our first specification check generally supports our previous findings, indicating that endogenous sorting of students into schools is a minor problem.

\section{Subsample who did not change schools-PISA 2003}

As a second robustness check to address the potential issue of endogenous sorting of students into schools, we restrict our sample to those students that have not changed schools during primary and lower secondary education (ISCED 1 and 2). Since PISA 2006 does not contain any information on the number of times students changed schools, we test our model (cf. equation (4)) using PISA 2003 data.

Our PISA 2003 sample is smaller than the PISA 2006 sample since our dependent variable, a measure of students' entrepreneurial intentions, was part of the optional Educational Career Questionnaire, which was not administered in all OECD countries. Columns (1) and (2) of Table 4 report the results of standard probit and IV probit analyses for our full (i.e., 16 countries) PISA 2003 sample. Given this somewhat different subsample of countries, it is remarkable that both estimates are very similar to the results we obtain from PISA 2006 data (shown in Table 2 above). 
Table 4. Robustness check 2: cross-country regressions, marginal effects after probit, calculated at the sample mean (PISA 2003)

Full sample Did not change schools

(1)

(2)

(3)

(4)

\begin{tabular}{lllll}
\hline either parent is an entrepreneur (definition 1) & $0.022^{* * *}$ & $0.022^{* * *}$ & $0.021^{* * *}$ & $0.022^{* * *}$ \\
& $(0.002)$ & $(0.002)$ & $(0.003)$ & $(0.003)$ \\
size of the entrepreneurial peer group (definition 1) & $0.101^{* * *}$ & $0.264^{* * *}$ & $0.107^{* * *}$ & $0.396^{* * *}$ \\
& $(0.011)$ & $(0.065)$ & $(0.014)$ & $(0.145)$ \\
Background variables & yes & yes & yes & yes \\
Observations & 83,847 & 83,847 & 51,325 & 51,325 \\
Countries & 16 & 16 & 15 & 15 \\
Peer group variable instrumented & no & yes & no & yes \\
\hline Notes: Dependent variable: students' entrepreneurial intentions (definition 1); standard errors in parentheses; \\
all models contain country fixed effects; each country is given equal weight; &
\end{tabular}

To minimize the problem of endogenous sorting of students into schools, we restrict our PISA 2003 sample to those students who never changed schools during ISCED1 (Primary Education) and ISCED2 (Lower Secondary Education). The rationale behind this is that, for this subsample, students' parents have opted to not change schools during ISCED 1 and 2. This solves the problem of endogenous sorting across schools during students' schooling career, but does not rule out the possibility of endogenous sorting at the beginning of ISCED 1 and 2.

The results of this robustness check are set out in columns (3) and (4) of Table 4. Our estimates for both the endogenous effect of the entrepreneurial peer group as well as the effect of having a parent who is an entrepreneur are slightly bigger than the ones we obtain from our full PISA 2003 sample, but not significantly so. This indicates that endogenous sorting during a student's schooling career appears to be a minor problem.

\section{Anti-test: peer group with different occupational intentions}

Another way of assessing the robustness of our results, as well as the validity of our model, is to conduct an anti-test, namely, by estimating our cross-country probit and IV probit models using the same dependent variable and regressors as in the models underlying Table 2, but with a different definition of the peer group.

We thus define the peer group as the share of students at school level intending to work in in the occupation group "Large Enterprise Director and Chief Executive" or "Large Enterprise Operation 
Department Manager". We argue that if we find a significant association between these so-defined peer groups and our dependent variable, namely students' entrepreneurial intentions, this would not be consistent with our theoretical model. In contrast, we can thus gauge the extent to which selection bias (i.e., endogenous sorting of students into schools) might bias our results in our basic model, the results of which we reported above in Table 2.

In our probit estimates of these antitests, we find a significantly positive relationship between the share of peers intending to be "Large Enterprise Director and Chief Executive" or a "Large Enterprise Operation Department Manager" and an individual 's intention to become an entrepreneur (columns (1) and (3) in Table 5.) This association is much smaller than that between the size of the entrepreneurial peer group and an individual's entrepreneurial intentions (see Table 2), and becomes statistically insignificant once we instrument the peer group with the share of peers whose parents are Large Enterprise Directors, Executives, or Operation Department Manager.

Table 5. Robustness check 3: Antitest, average marginal effects after probit and IV probit, evaluated at the sample mean of all regressors

\begin{tabular}{lccc}
\hline \hline & & & \\
& & $(1)$ & $(3)$ \\
\hline either parent is an entrepreneur (definition 1) & $0.034^{* * *}$ & $0.030^{* * *}$ & $0.031^{* * *}$ \\
& $(0.002)$ & $(0.002)$ & $(0.002)$ \\
Size of the peer group & $0.040^{* *}$ & $0.036^{* *}$ & -0.003 \\
& $(0.017)$ & $(0.015)$ & $(0.125)$ \\
Background variables & no & yes & yes \\
Observations & 204,074 & 204,074 & 204,074 \\
Countries & 28 & 28 & 28 \\
Peer group variable instrumented & no & no & yes \\
\hline
\end{tabular}

Notes: Dependent variable: : students' entrepreneurial intentions (definition 1). Peer group defined as the share of students in the same school intending to take up an occupation as Corporate Managers, Directors \& Chief Executives, or Department Managers [Large Enterprises]

* significant at $10 \% ; * *$ significant at $5 \% ; * * *$ significant at $1 \%$

Overall, the results of this anti-test support our theoretical model and the validity of our empirical approach. The results do not support the hypothesis that an omitted variable bias due to an unobserved variable at school level biases our findings.

\section{Subsample "ISCED designation is general"}

As a fourth robustness check, we restrict our sample to only those students enrolled in programs that are not pre-vocational or vocational, according to the information on program destination (ISCEDD) 
contained in the PISA 2006 data set. ${ }^{20}$ The rationale behind this approach is that students in prevocational or vocational programs are assumed to be more aware of which occupation they are best suited for compared to students in general programs, which could make it difficult to concentrate on the identity part of the occupational choice.

\section{Table 6. Robustness check: General vs. vocational programme designation, regression coefficients marginal effects (evaluated at the sample mean of all regressors)

$\begin{array}{cc}\text { ISCEDD GENERAL } & \text { ISCEDD } \\ \text { VOCATIONAL }\end{array}$

$(2)$

\begin{tabular}{lcccc}
\hline either parent is an entrepreneur & $0.027^{* * *}$ & $0.027^{* * *}$ & $0.029^{* *}$ & $0.004^{* *}$ \\
(definition 1) & $(0.002)$ & $(0.002)$ & $(0.009)$ & $(0.002)$ \\
size of the entrepreneurial peer group & $0.088^{* * *}$ & $0.223^{* * *}$ & $0.140^{* * *}$ & $0.361^{* * *}$ \\
(definition 1) & $(0.010)$ & $(0.056)$ & $(0.033)$ & $(0.134)$ \\
Background variables & yes & yes & yes & yes \\
Observations & 152,340 & 152,340 & 18,006 & 18,006 \\
Countries & 26 & 26 & 10 & 10 \\
Peer group variable instrumented & no & yes & no & yes \\
\hline
\end{tabular}

Notes: Dependent variable: students' entrepreneurial intentions (definition 1).

$*$ significant at $10 \%$; * significant at $5 \%$;** significant at $1 \%$

Columns (1) and (2) of Tables 6 show the results for the subsample of students not enrolled in vocational or pre-vocational programs; Columns (3) and (4) contain the results for the subsample of students in programs that lead to direct access to the labor market. For the students not enrolled in pre-vocational or vocational programs, the coefficient on parental entrepreneurial status is significantly positive and similar in size to that in the standard probit model contained in Table 2. Also, the peer effect remains significantly positive in the subsample of students not enrolled in prevocational or vocational programs. It is interesting to note, however, that the peer effect appears to be somewhat bigger in the subsample of students in programs that lead to direct access to the labor market (see Columns (3) and (4) in Table 6). These results show that the endogenous peer effect we observe in our full sample is not merely driven by those students who plan to enter the labor market in the near future and who may thus have already collected first labor market experiences in the form of internships or hands-on training in school. This supports our argument that students' occupational intentions are not chiefly driven by consideration of ability.

\footnotetext{
${ }^{20}$ However, the classification in PISA 2006 (ISCED designation) appears problematic in at least two cases: in Germany, 97.5 percent of all students are enrolled in programs that give access to the next program level (as opposed to direct access to the labor market), while in the United Kingdom, over 90 percent of all students are enrolled in programs that give direct access to the labor market.
} 


\section{Summary}

In this paper we analyze the relationship between an individual's identity and his or her intention of becoming an entrepreneur. In our theoretical model, identity is assumed to be shaped by the individual's parents and peers. Analyzing data from the Programme for International Student Assessment (PISA) 2006, we find that having parents in an entrepreneurial occupation has a positive impact on an individual's intention to become an entrepreneur (Hypothesis 1). Controlling for students' test scores, for example, as well as for their family's socioeconomic background, does not alter the results, indicating that omitted variable bias due to unobserved ability of parents and students is a minor problem. Similarly, having entrepreneurially inclined peers increases the probability of the student intending to become an entrepreneur. In particular, we address Manski's (1995) reflection problem by means of an instrumental variable strategy, using the share of students at school who have entrepreneurial parents as an instrument for the share of entrepreneurially inclined peers at school. Assuming that contextual effects are absent in our setting, we conclude that there are endogenous peer effects on the intention to become an entrepreneur, supporting our second hypothesis. These results are robust to the inclusion of school fixed effects in a subsample of the PISA 2006 data, and are robust when using PISA 2003 data and when restricting the sample to students who did not change school during primary and lower secondary education. For the latter group, endogenous sorting across schools is less likely.

With regard to entrepreneurship education, offering entrepreneurship classes at business schools might be a good way for students to learn the tools necessary to run a business, but it is not likely that any sort of course can work to develop an entrepreneurial identity. Techniques and procedures can be learned, but the entrepreneurial spirit necessary for their successful deployment cannot - this essential attribute is the result, instead, of the environment in which an individual has grown up.

We therefore conclude that fostering an entrepreneurial identity is a long-run task that needs to begin at an early age, both for individuals and for society at large, as we have found that it is the entrepreneurial characteristics of both parents and peers that have the most influence on the formation of an entrepreneurial identity. However, our data do not allow discovery of the exact transmission mechanism behind this phenomenon and we thus strongly encourage further research that focuses on the intertemporal development of an individual's entrepreneurial identity. 


\section{References}

Aghion, P., and P. Howitt (1992). "A Model of Growth Through Creative Destruction." Econometrica, 60(2), 323-51.

Akerlof, G. A. (1997). “Social Distance and Social Decisions.” Econometrica, 65(5), 1005-1027.

Akerlof, G. A. and R. E. Kranton (2005). "Identity and the Economics of Organizations." Journal of Economic Perspectives, 19(1), 9-32.

Akerlof, G. A., and R. E. Kranton (2000). "Economics and Identity.” Quarterly Journal of Economics 105(3), 715-53.

Aldrich, H., L. A. Renzulli, and N. Langton (1998). "Passing on Privilege: Resources Provided by Self-Employed Parents to Their Self-Employed Children." Research in Social Stratification and Mobility, 16, 291-317.

Arrow, K. J. (1962). "Economic Welfare and the Allocation of Resources for Innovation," in: R. R. Nelson (ed.), The Rate and Direction of Inventive Activity, 609-26. Princeton, NJ: Princeton University Press.

Bandura, A. (1977). Social Learning Theory. Englewood Cliffs, NJ: Prentice Hall.

Bandura, A. (1986). Social Foundations of Thought and Action. Englewood Cliffs, NJ: Prentice Hall.

Baron, R. A. (1998). "Cognitive Mechanisms in Entrepreneurship: Why and When Entrepreneurs Think Differently Than Other People.” Journal of Business Venturing, 13(4), 275-94.

Bauernschuster, S., O. Falck, and S. Heblich (2008). Occupational Choice and Social Contacts Across Regions. Jena Economic Research Papers 2008-079.

Baumol, W. (1968). "Entrepreneurship in Economic Theory." American Economic Review, 58(2), 64-71.

Becker, G. S. (1991). "A Note on Restaurant Pricing and Other Examples of Social Influences on Price.” Journal of Political Economy, 99, 1109-1116.

Becker, G. S., and K. M. Murphy (1993). "A Simple Theory of Advertising as a Good or Bad." Quarterly Journal of Economics, 108, 941-964.

Björklund, A., M. Jäntti, and G. Solon (2007). Nature and Nurture in the Intergenerational Transmisson of Socioeconomic Status: Evidence from Swedish Children and Their Biological and Rearing Parents. Working Paper, Michigan State University.

Bloom, A. (1987). The Closing of the American Mind. New York: Simon and Schuster.

Camerer, C., and D. Lovallo (1999). "Overconfidence and Excess Entry: An Empirical Approach.” American Economic Review, 89, 306-18. 
Coleman, J. S. (1961). The Adolescent Society: The Social Life of the Teenager and Its Impact on Education. New York: Free Press.

Coleman, J. S. (1988). "Social Capital in the Creation of Human Capital." American Journal of Sociology, 9, 95-121.

Cunha, F., and J. Heckman (2007). "The Technology of Skill Formation.” American Economic Review, 97(2), 31-47.

Deaton, A. (1997). The Analysis of Household Surveys: A Microeconometric Approach to Development Policy. Baltimore: Johns Hopkins University Press.

Dohmen, T, A. Falk, D. Huffman, and U. Sunde (2006). The Intergenerational Transmission of Risk and Trust Attitudes. IZA Discussion Paper No. 2380.

DuMouchel, W. H., and G. J. Duncan (1983). "Using Sample Survey Weights in Multiple Regression Analyses of Stratified Samples." Journal of the American Statistical Association, 78(383), 535-43.

Dunn, T., and D. Holtz-Eakin (2000). "Financial Capital, Human Capital, and the Transition to SelfEmployment: Evidence from Intergenerational Links." Journal of Labor Economics, 18(2), 282-305.

Eckert, P. (1995). "Trajectory and forms of institutional participation. In: L. J. Crockett and A. C. Crouter (Eds.): Pathways Through Adolescence, 175-195, New Jersey: L. Erlbaum.

European Commission (2006). "Entrepreneurship Education in Europe: Fostering Entrepreneurial Mindsets Through Education and Learning." Final Proceedings of the Conference on Entrepreneurship Education in Oslo.

Evans, D. S., and L. S. Leighton (1989). "Some Empirical Aspects of Entrepreneurship." American Economic Review, 79, 519-35.

Feldman, M. P. (2001). "The Entrepreneurial Event Revisited: Firm Formation in a Regional Context." Industrial and Corporate Change, 10(4), 861-891.

Fuchs, T., and L. Wößmann (2007). "What Accounts for International Differences in Student Performance? A Re-Examination Using PISA Data.” Empirical Economics, 32(2-3), 433-64.

Gaviria, A., and S. Raphael (2001). "School-based Peer Effects and Juvenile Behavior." The Review of Economics and Statistics, 83(2), 257-268.

Granovetter, M. (1985). "Economic Action and Social Structures: The Problem of Embeddedness." American Journal of Sociology, 91, 481-510.

Greene, F., K. Mole, and D. J.Storey (2008). Three Decades of Enterprise Culture. London: Palgrave.

Halaby, C. N. (2003). "Where Job Values Come From: Family and Schooling Background, Cognitive Ability, and Gender", American Sociological Review, 68, 251-278.

Hamilton, B. H. (2000). "Does Entrepreneurship Pay? An Empirical Analysis of the Returns of SelfEmployment." Journal of Political Economy, 108, 604-31.

Hayek, F. A. von (1937). “Economics and Knowledge.” Economica, New Series, 4(13), 33-54. 
Heckman (2006). Skill Formation and the Economics of Investing in Disadvantaged Children. Science, 312, 1900-1902.

Holtz-Eakin, D., D. Joulfaian, and H. S. Rosen (1994). "Sticking It Out: Entrepreneurial Survival and Liquidity Constraints." JP.E. 102, 53-75.

Hout, M., and H. Rosen (2000). "Self-Employment, Family Background, and Race." Journal of Human Resources, 35, 670-92.

International Labour Organisation (ILO) (1990). International Standard Classification of Occupations: ISCO-88. Geneva: International Labour Office.

Johnson, M. K. (2002). "Social Origins, Adolescent Experiences, and Work Value Trajectories During the Transition to Adulthood." Social Forces 80, 1307-40.

Kahneman, D., and A. Tversky (1979). "Prospect Theory: An Analysis of Decision Under Risk." Econometrica, 47(2), 263-92.

Kanbur, S., and M. Ravi (1990). "Entrepreneurial Risk Taking, Inequality, and Public Policy: An Application of Inequality Decomposition Analysis to the General Equilibrium Effects of Progressive Taxation." Journal of Political Economy, 90, 1-21.

Keeble, D., and S.Walker (1994). "New Firms, Small Firms and Dead Firms: Spatial Patterns and Determinants in the United Kingdom." Regional Studies 28: 411-427

Kihlstrom, R. E., and J.-J. Laffont (1979). “A General Equilibrium Entrepreneurial Theory of Firm Formation Based on Risk Aversion." Journal of Political Economy, 87, 719-48.

Knight, F. H. (1921). Risk, Uncertainty and Profit, New York: Houghton Mifflin.

Kuratko, D. F. (2005). "The Emergence of Entrepreneurship Education: Development, Trends, and Challenges.” Entrepreneurship Theory and Practice, 29(5), 577-98.

Lazear, E. P. (2005). “Entrepreneurship.” Journal of Labor Economics, 23, 649-80.

Lentz , B. F. and S. Laband (1990). "Entrepreneurial Success and Occupational Inheritance Among Proprietors." Canadian Journal of Economics, 23(3), 101-17.

Lucas, R. E. Jr. (1978). “On the Size Distribution of Business Firms.” Bell Journal of Economics, 2 , 508-23.

Manski, C.F. (1995). Identification Problems in the Social Sciences. Cambridge: Harvard University Press.

Marshall, A. (1920). Principles of Economics, $8^{\text {th }}$ ed. London: MacMillan.

Michelacci, C., and O. Silva (2007). "Why So Many Local Entrepreneurs?" Review of Economics and Statistics, 89(4), 615-33.

Miller, W. (1952). The Business Elite in Business Bureaucracies. In: W. Miller (Ed.): Men in Business: Essays in the History of Entrepreneurship, 286-305. Cambridge: Harvard University Press.

Mitchell, R., and D. Shepherd (2008). "To Thine Own Self be True: Images of Self, Images of Opportunity, and Entrepreneurial Action.” Journal of Business Venturing, in press. 
Mortimer, J. T., and J. Lorence (1979). "Work Experience and Occupational Value Socialization: A Longitudinal Study." American Journal of Sociology, 84, 1361-85.

Moulton, B. R. (1986), "Random Group Effects and the Precision of Regression Estimates." Journal of Econometrics, 32(3), 385-97.

Neu, I.D., and F.W. Gregory (1952). The American Industrial Elite in the 1870s: Their Social Origins. In: W. Miller (Ed.): Men in Business: Essays in the History of Entrepreneurship, 193211. Cambridge: Harvard University Press.

Neyman and Scott (1948). "Consistent Estimates based on partially consistent observations." Econometrica, 16, 1-32.

Norton, E. C., R. C. Lindrooth, and S. T. Ennett (1998). "Controlling for the Endogeneity of Peer Substance Use on Adolescent Alcool and Tobacco Use." Health Economics, 7, 439-453.

Oosterbeek H., M. van Praag, and A. IJsselstein (2008). The Impact of Entrepreneurship Education on Entrepreneurship Competencies and Intentions: An Evaluation of the Junior Achievement Student Mini-Company Program. IZA Discussion Paper No. 3641.

Organisation for Economic Co-operation and Development (OECD) (2007a). PISA 2006 Science Competencies for Tomorrow's World. Volume 1: Analysis. Paris: OECD.

Organisation for Economic Co-operation and Development (OECD) (2007b). PISA 2006 Science Competencies for Tomorrow's World. Volume 2: Data. Paris: OECD.

Parker, S. C. (2004). The Economics of Self-Employment and Entrepreneurship. Cambridge: Cambridge University Press.

Parker, S. C. (2009). Small firms and innovation, forthcoming in: D. B. Audretsch et al. (eds.), Handbook of Research on Innovation and Entrepreneurship. Cheltenham: Edward Elgar.

Saxenian, A. 1999. Silicon Valley's New Immigrant Entrepreneurs, San Francisco: Public Policy Institute of California.

Sanders, J. M., and V. Nee (1996). "Immigrant Self-Employment: The Family as Social Capital and the Value of Human Capital." American Sociological Review, 61, 231-49.

Schneeweis, N., Winter-Ebmer, R. (2007). "Peer Effects in Austrian schools." Empirical Economics, 32, 387 - 409.

Schumpeter, J. A. (1912). The Theory of Economic Development. New York: Oxford University Press.

Sen A. (1977). Rational Fools: A Critique of the Behavioral Foundations of Economic Theory, Philosophy and Public Affairs, 6, 317-344.

Solon, G. (1999). "Intergenerational mobility in the labor market." In O. Ashenfelter and D. E. Card (Eds.) Handbook of Labor Economics, 1761-1800, North Holland, Elesevier.

Stuart, T. E., and O. Sorenson (2005). "Social Networks and Entrepreneurship," in: S. Alvarez, R. Agarwal, and O. Sorenson (eds.), The Handbook of Entrepreneurship: Disciplinary Perspectives, 211-28. Berlin: Springer. 
Trogdon, J. G., J. Nonnemaker, and J. Pais (2008). "Peer effects in adolescent overweight." Journal of Health Economics, 27, 1388-1399.

Wooldridge, J. M. (2001). “Asymptotic Properties of Weighted M-Estimators for Standard Stratified Samples." Econometric Theory, 17(2), 451-70.

Wu, B., and A. M: Knott (2006). "Entrepreneurial Risk and Market Entry.” Management Science, 52(9), 1315-30. 


\section{Appendix}

\section{Appendix A1. List of control variables from the PISA school and student background questionnaires}

\section{A1.1 Final list of control variables}

\section{Individual and family background variables}

- $\quad$ Student is female

- Student is first generation immigrant

- Student is a second generation immigrant

- PISA Index of family wealth

- Highest level of educational attainment of parents, converted into an index of years of schooling (PARED)

- Students' test scores (Mathematics, Science)

\section{School background variables}

\section{A. Measures of school location}

- School located in a village, hamlet or rural area (fewer than 3000 people)

- School located in a small town (3000 to about 15000 people)

- School located in a town (15000 to about 100000 people)

- School located in a city (100 000 to about 1000000 people)

- School located in a large city (with over 1000000 people)

B. Indices of socio-economic composition of the school

- Share of immigrant students at school

- School average parental education

- School average index of family wealth

Institutional characteristics and schools' resource endowment:

- Students' learning time for regular lessons in school

- Students' learning time for out-of-school lessons

- Students' learning time for self-study or homework

A1.2 Potential control variables that were tested, but that were not significantly related to students' entrepreneurial intentions

\section{Individual and family background variables}

- Student speaks the test language or other national language most of the time or always at home

- Grade (set of dummy variables)

- Student has ever repeated a grade

School background variables

- School size

- Share of girls at school

Institutional characteristics and schools' resource endowment: a. Admission practices, selectivity and ability grouping

- School with ability grouping for all subjects within school

- School with high academic selectivity of school admittance

b. School management and funding

- School being privately managed

- Proportion of school funding from government sources

c. Parental pressure and school competition

- School with high level of competition

- School with high levels of perceived parental pressure

d. Accountability

- School informing parents of children's performance relative to other students in school 
- School informing parents of children's performance relative to national benchmarks

- School informing parents of students' performance relative to other schools

- School posting achievement data publicly

- School using achievement data for evaluating principals

- School using achievement data for evaluating teachers

- School using achievement data for allocating resources to schools

- School with achievement data tracked over time

\section{e. School autonomy}

- in hiring teachers

- in firing teachers

- in establishing teachers' starting salaries

- in determining teachers' salaries increases

- in formulating the school budget

- in deciding on budget allocations within the school

- in establishing student disciplinary policies

- in establishing student assessment policies

- in approving students for admission to the school

- in choosing which textbooks are used

- in determining course content

- in deciding which courses are offered

\section{f. School resources}

- School average number of students per teacher

- School-level index of teacher shortage

- School average number of computers for instruction per student

- School-level index of quality of school educational resources

\section{g. Business influence and activities}

- Students participate in job fairs, lectures (at school) by business or industry representatives or visits to local businesses or industries at least once a year

- some students receive some training within local businesses as part of school activities during the normal school year

- Business and industry have a considerable influence on the curriculum

\section{h. Career guidance}

- Career guidance is provided by teachers at school

- Career guidance is provided by specific career guidance counsellors employed at school or regularly visiting the school 


\section{CESifo Working Paper Series}

for full list see www.cesifo-group.org/wp

(address: Poschingerstr. 5, 81679 Munich, Germany, office@cesifo.de)

2601 Ana B. Ania and Andreas Wagener, The Open Method of Coordination (OMC) as an Evolutionary Learning Process, April 2009

2602 Simon Gächter, Daniele Nosenzo, Elke Renner and Martin Sefton, Sequential versus Simultaneous Contributions to Public Goods: Experimental Evidence, April 2009

2603 Philippe Jehiel and Andrew Lilico, Smoking Today and Stopping Tomorrow: A Limited Foresight Perspective, April 2009

2604 Andreas Knabe, Steffen Rätzel, Ronnie Schöb and Joachim Weimann, Dissatisfied with Life, but Having a Good Day: Time-Use and Well-Being of the Unemployed, April 2009

2605 David Bartolini and Raffaella Santolini, Fiscal Rules and the Opportunistic Behaviour of the Incumbent Politician: Evidence from Italian Municipalities, April 2009

2606 Erkki Koskela and Jan König, Can Profit Sharing Lower Flexible Outsourcing? A Note, April 2009

2607 Michel Beine, Frédéric Docquier and Çağlar Özden, Diasporas, April 2009

2608 Gerd Ronning and Hans Schneeweiss, Panel Regression with Random Noise, April 2009

2609 Adam S. Booij, Bernard M.S. van Praag and Gijs van de Kuilen, A Parametric Analysis of Prospect Theory's Functionals for the General Population, April 2009

2610 Jeffrey R. Brown, Julia Lynn Coronado and Don Fullerton, Is Social Security Part of the Social Safety Net?, April 2009

2611 Ali Bayar and Bram Smeets, Economic, Political and Institutional Determinants of Budget Deficits in the European Union, April 2009

2612 Balázs Égert, The Impact of Monetary and Commodity Fundamentals, Macro News and Central Bank Communication on the Exchange Rate: Evidence from South Africa, April 2009

2613 Michael Melvin, Christian Saborowski, Michael Sager and Mark P. Taylor, Bank of England Interest Rate Announcements and the Foreign Exchange Market, April 2009

2614 Marie-Louise Leroux, Pierre Pestieau and Gregory Ponthiere, Should we Subsidize Longevity?, April 2009

2615 Ronald MacDonald, Lukas Menkhoff and Rafael R. Rebitzky, Exchange Rate Forecasters' Performance: Evidence of Skill?, April 2009 
2616 Frederick van der Ploeg and Steven Poelhekke, The Volatility Curse: Revisiting the Paradox of Plenty, April 2009

2617 Axel Dreher, Peter Nunnenkamp, Hannes Öhler and Johannes Weisser, Acting Autonomously or Mimicking the State and Peers? A Panel Tobit Analysis of Financial Dependence and Aid Allocation by Swiss NGOs, April 2009

2618 Guglielmo Maria Caporale, Roman Matousek and Chris Stewart, Rating Assignments: Lessons from International Banks, April 2009

2619 Paul Belleflamme and Martin Peitz, Asymmetric Information and Overinvestment in Quality, April 2009

2620 Thomas Dohmen, Armin Falk, David Huffman and Uwe Sunde, Are Risk Aversion and Impatience Related to Cognitive Ability?, April 2009

2621 Yin-Wong Cheung and Xingwang Qian, The Empirics of China's Outward Direct Investment, April 2009

2622 Frédérique Bec and Christian Gollier, Assets Returns Volatility and Investment Horizon: The French Case, April 2009

2623 Ronnie Schöb and Marcel Thum, Asymmetric Information Renders Minimum Wages Less Harmful, April 2009

2624 Martin Ruf and Alfons J. Weichenrieder, The Taxation of Passive Foreign Investment Lessons from German Experience, April 2009

2625 Yao Li, Borders and Distance in Knowledge Spillovers: Dying over Time or Dying with Age? - Evidence from Patent Citations, April 2009

2626 Jim Malley and Ulrich Woitek, Technology Shocks and Aggregate Fluctuations in an Estimated Hybrid RBC Model, April 2009

2627 Jin Cao and Gerhard Illing, Endogenous Systemic Liquidity Risk, April 2009

2628 Thiess Buettner and Bjoern Kauder, Revenue Forecasting Practices: Differences across Countries and Consequences for Forecasting Performance, April 2009

2629 Håkan Selin, The Rise in Female Employment and the Role of Tax Incentives - An Empirical Analysis of the Swedish Individual Tax Reform of 1971, April 2009

2630 Nick Johnstone and Ivan Hascic, Environmental Policy Design and the Fragmentation of International Markets for Innovation, April 2009

2631 Spiros Bougheas, Richard Kneller and Raymond Riezman, Optimal Education Policies and Comparative Advantage, April 2009

2632 Jay Pil Choi and Heiko Gerlach, Multi-Market Collusion with Demand Linkages and Antitrust Enforcement, April 2009 
2633 Thor O. Thoresen, Income Mobility of Owners of Small Businesses when Boundaries between Occupations are Vague, April 2009

2634 Guido Schwerdt and Amelie C. Wuppermann, Is Traditional Teaching really all that Bad? A Within-Student Between-Subject Approach, April 2009

2635 Kurt R. Brekke, Luigi Siciliani and Odd Rune Straume, Hospital Competition and Quality with Regulated Prices, April 2009

2636 Peter Diamond, Taxes and Pensions, April 2009

2637 Shoshana Grossbard, How "Chicagoan" are Gary Becker's Economic Models of Marriage?, May 2009

2638 Roland Strausz, Regulatory Risk under Optimal Incentive Regulation, May 2009

2639 Holger Zemanek, Ansgar Belke and Gunther Schnabl, Current Account Imbalances and Structural Adjustment in the Euro Area: How to Rebalance Competitiveness, May 2009

2640 Harald Hau and Marcel Thum, Subprime Crisis and Board (In-)Competence: Private vs. Public Banks in Germany, May 2009

2641 Martin Halla, Mario Lackner and Friedrich G. Schneider, An Empirical Analysis of the Dynamics of the Welfare State: The Case of Benefit Morale, May 2009

2642 Balázs Égert, Infrastructure Investment in Network Industries: The Role of Incentive Regulation and Regulatory Independence, May 2009

2643 Christian Gollier, Expected Net Present Value, Expected Net Future Value, and the Ramsey Rule, May 2009

2644 Sören Blomquist and Håkan Selin, Hourly Wage Rate and Taxable Labor Income Responsiveness to Changes in Marginal Tax Rates, May 2009

2645 Dominique Demougin, Oliver Fabel and Christian Thomann, Implicit vs. Explicit Incentives: Theory and a Case Study, May 2009

2646 Francesco C. Billari and Vincenzo Galasso, What Explains Fertility? Evidence from Italian Pension Reforms, May 2009

2647 Kjell Arne Brekke, Karen Evelyn Hauge, Jo Thori Lind and Karine Nyborg, Playing with the Good Guys - A Public Good Game with Endogenous Group Formation, May 2009

2648 Guglielmo Maria Caporale and Luis A. Gil-Alana, Multi-Factor Gegenbauer Processes and European Inflation Rates, May 2009

2649 Henning Bohn, A Static Model for Voting on Social Security, May 2009

2650 Markus Haavio and Kaisa Kotakorpi, The Political Economy of Sin Taxes, May 2009 
2651 Augusto de la Torre, María Soledad Martínez Pería and Sergio L. Schmukler, Drivers and Obstacles to Banking SMEs: The Role of Competition and the Institutional Framework, May 2009

2652 Tobias Lindhe and Jan Södersten, Dividend Taxation, Share Repurchases and the Equity Trap, May 2009

2653 Assaf Razin and Edith Sand, Migration-Regime Liberalization and Social Security: Political-Economy Effect, May 2009

2654 Yin-Wong Cheung and Hiro Ito, A Cross-Country Empirical Analysis of International Reserves, May 2009

2655 Bart Cockx and Bruno Van der Linden, Flexicurity in Belgium. A Proposal Based on Economic Principles, May 2009

2656 Michael Melvin, Lukas Menkhoff and Maik Schmeling, Exchange Rate Management in Emerging Markets: Intervention via an Electronic Limit Order Book, May 2009

2657 Susanne Neckermann, Reto Cueni and Bruno S. Frey, What is an Award Worth? An Econometric Assessment of the Impact of Awards on Employee Performance, May 2009

2658 Steven Brakman, Harry Garretsen and Charles van Marrewijk, Economic Geography within and between European Nations: The Role of Market Potential and Density across Space and Time, May 2009

2659 Giovanni Facchini and Cecilia Testa, Reforming Legislatures: Is one House better than two?, May 2009

2660 Carsten Kowalczyk and Raymond Riezman, Trade Agreements, May 2009

2661 Oliver Falck, Stephan Heblich and Elke Luedemann, Identity and Entrepreneurship, May 2009 